\title{
Correspondence
}

https://doi.org/10.11646/phytotaxa.391.2.11

\section{Glenodinium triquetrum Ehrenb. is a species not of Heterocapsa F.Stein but of Kryptoperidinium Er.Lindem. (Kryptoperidiniaceae, Peridiniales)}

\author{
MARC GOTTSCHLING ${ }^{1, *}$, URBAN TILLMANN ${ }^{2}$, MALTE ELBRÄCHTER ${ }^{3}$, WOLF-HENNING KUSBER ${ }^{4} \&$ MONA \\ HOPPENRATH ${ }^{5}$ \\ ${ }^{1}$ Department Biologie, Systematische Botanik und Mykologie, GeoBio-Center, Ludwig-Maximilians-Universität München, Menzinger \\ Str. 67, D-80638 München, Germany \\ ${ }^{2}$ Alfred-Wegener-Institut, Helmholtz-Zentrum für Polar-und Meeresforschung, Am Handelshafen 12, D - 27570 Bremerhaven, Germany \\ ${ }^{3}$ Alfred-Wegener-Institut, Helmholtz-Zentrum für Polar- und Meeresforschung, Wattenmeerstation Sylt, Hafenstr. 43, D - 25992 List/ \\ Sylt, Germany \\ ${ }^{4}$ Botanischer Garten und Botanisches Museum Berlin, Freie Universität Berlin, Königin-Luise-Straße 6-8, D - 14195 Berlin, Germany \\ ${ }^{5}$ Senckenberg am Meer, German Centre for Marine Biodiversity Research (DZMB), Südstrand 44, D- 26382 Wilhelmshaven, Germany \\ *corresponding author, e-mail: gottschling@bio.lmu.de
}

\section{Introduction}

The dinophyte names Heterocapsa F.Stein and Kryptoperidinium Er.Lindem. are linked in a unfortunate way: The type of Heterocapsa, namely the well-established Heterocapsa triquetra (Ehrenb.) F.Stein, is demonstrably an element of Kryptoperidinium in its current circumscription (Gottschling et al. 2018b). This was uncovered 130 years after the combination from Glenodinium Ehrenb. to Heterocapsa was made (Stein 1883: 13), and we aim at overcoming the severe nomenclatural and taxonomical consequences (Gottschling et al. 2018b) by the proposal to conserve the type of Heterocapsa (Gottschling et al. 2018a) with Heterocapsa steinii Tillmann, Gottschling, Hoppenrath, Kusber \& Elbr. (Tillmann et al. 2017). The latter species is typified on etchings from F. von Stein's seminal work (Stein 1883: pl. III 35) that thus, the traditional concept of Heterocapsa is maintained once the proposal is accepted.

The basionym Glenodinium triquetrum Ehrenb. was described from the Baltic Sea off Wismar (Germany), collected in September 1840 (Ehrenberg 1840). Corresponding water-colour drawings (Fig. 1 in Gottschling et al. 2018b) show yellow-green dinophyte cells that are ovate through elliptical in dorsal or ventral view and have an eyespot (the reason why the species was initially described under Glenodinium). The epithet refers to the diagnostic triangular outline in lateral view, a result of ventral (and concave) flattening of the cell, doubtlessly assigning the taxon to Kryptoperidinium in its accepted concept. More than forty years later, Stein (1883: pl. III 22-26) described and illustrated cells very similar to Ch.G. Ehrenberg's original material (likewise from the Baltic Sea off Wismar) as a new species, namely Glenodinium foliaceum F.Stein. In addition, the combinations Kryptoperidinium foliaceum (F.Stein) Er.Lindem. and Peridinium foliaceum (F.Stein) Biecheler, respectively, were the accepted names for the species since then.

Kryptoperidinium belongs to a small group of dinophytes hosting a tertiary endosymbiont derived from a diatom (Dodge 1971, Horiguchi \& Pienaar 1994, Schnepf \& Elbrächter 1999), namely the Kryptoperidiniaceae that are a wellsupported monophyletic group in molecular phylogenetics (Kretschmann et al. 2018). Evolutionarily, the endosymbiont may replace the original chloroplast being still present as unique type of eye spot (Schnepf \& Elbrächter 1999, Moestrup \& Daugbjerg 2007). The presence of a diatom endosymbiont (i.e., relatives of Nitzschia Hassall, nom. cons.: Ross 1952, Anonymous 1954) in Kryptoperidinium was reported in many cases, but populations without such compartment were also noted (Kempton et al. 2002). Cells without endosymbiont nucleus but chloroplasts were personally observed by one of us authors (ME) in material collected in the Baltic Sea off Hiddensee, confirming previous observations from elsewhere (Chatton 1952). Such observations challenge the assumption that the mutualism is entirely obligatory (Žerdoner Čalasan et al. 2018) or could also indicate the existence of different species. Similarly, cells with and without eye spot (Kempton et al. 2002, Saburova et al. 2012) were reported, whereas the eye spot can degenerate in strains of older ages (Moldrup et al. 2013).

Kryptoperidinium circumscribes very peculiar dinophytes, last but not least because of the characteristic ventral flattening of the cell (Ehrenberg 1840, Stein 1883, Lindemann 1924, Gottschling et al. 2018b). In molecular trees, two distinct ribotypes of Kryptoperidinium can be distinguished (Gottschling \& McLean 2013, Kretschmann et al. 2018, Žerdoner Čalasan et al. 2018; Fig. 1). Such ribotypes may represent different species and may correlate to the presence of either four 
(in strains, e.g., NCMA1326 and UTEX1688: Kempton et al. 2002) or five cingular plates (in strains, e.g., CCAP1116/3 and GeoB 459: Fig. 2), but this must be precisely worked out in future research. Furthermore, cells with only three instead of otherwise four apical plates have been documented (Figueroa et al. 2009) but unfortunately, no sequence data are available from such material for further comparison.

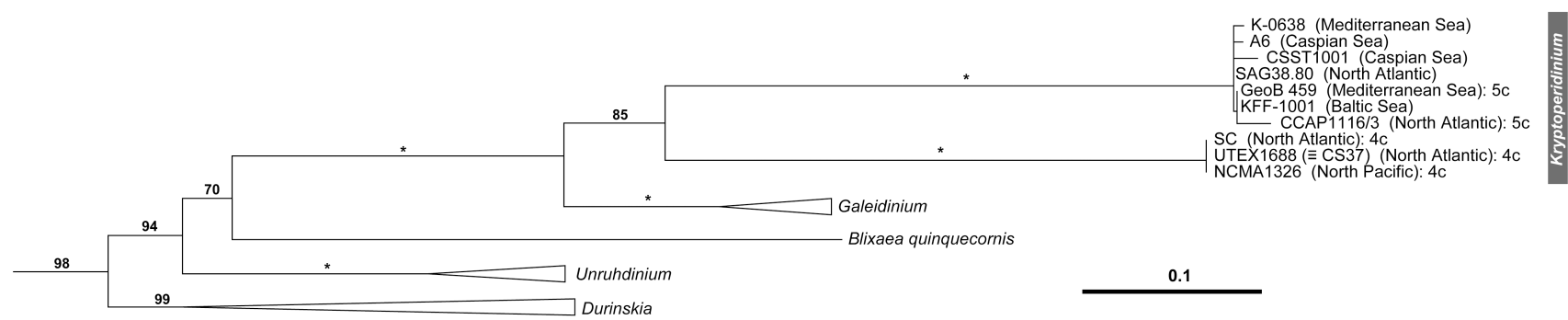

FIGURE 1. Maximum Likelihood (ML) tree of 46 Kryptoperidiniaceae operational taxonomic units, derived from the comparison of concatenated rRNA sequences (cut-off from Kretschmann et al. 2018, with all available sequences of Kryptoperidinium included). Branch lengths are drawn to scale, with the scale bar indicating the number of nt substitutions per site. The numbers on the branches are ML bootstrap values (values $<50$ are not shown). Asterisks indicate maximal support. Numbers of cingular plates are indicated (as far as such information is available).


FIGURE 2. Morphology of Kryptoperidinium cf. triquetrum, comb. nov. (strain GeoB 459 from the Mediterranean Sea). Plates are labelled using the Kofoidean system (A: light microscopy, B-C: calcofluor white staining). A. ventral view. B. ventral view. C. dorsal view. Scale bars $=5 \mu \mathrm{m}$.

At present, a single species of Kryptoperidinium is broadly accepted, namely $K$. foliaceum, but there is evidence for considerable diversity regarding both morphology and DNA sequence data. Thus, taxonomy of Kryptoperidinium and its constituent species remains to be clarified, and the taxa Glenodinium foliaceum var. ponticum Roukh. from the Black Sea, Glenodinium monense Herdman from Port Erin in the Irish Sea, Peridinium cuneatum Goor from Dutch Krommeniedijk and Phyllodinium scutelaris W.Conrad from Belgian Nieuwpoort may prove helpful to provide the observed diversity with scientific names. Anyhow, the taxonomy of the oldest name published in Kryptoperidinium (i.e., Kryptoperidinium triquetrum, comb. nov.) should be clarified with priority. As first step, a lectotype was designated for G. triquetrum in Gottschling et al. (2018b; see below).

Irrespectively of the question whether there are more than a single species of Kryptoperidinium, the taxonomic identities of the Baltic taxa remain obscure. Neither Ehrenberg (1840) nor Stein (1883) provided traits such as the Kofoidean plate pattern and particularly the number of cingular plates. Furthermore, neither the descriptions nor the illustrations of Ch.G. Ehrenberg and Stein (1883) allow reliable conclusions about presence or absence of diatom endosymbionts for Baltic Kryptoperidinium. Anyhow, presence of Kryptoperidinium was recently confirmed for the Baltic Sea as inferred from molecular sequence data (strain KFF-1001 deposited as GenBank entry LT906378) but here, morphological information for this strain is currently not available. 
Both taxa K. foliaceum and K. triquetrum, comb. nov., are described from the Baltic Sea off Wismar and because of overall similarity, conspecificity is very likely. To disentangle the taxonomy, it remains an important future task to collect living material at the type locality off Wismar for contemporary study. Anyhow, the basionym of K. triquetrum, comb. nov., is more than forty years older than the basionym of $K$. foliaceum and thus has taxonomic priority. It was never assigned to Kryptoperidinium because of the taxonomic confusion associated with a species of Heterocapsa (Tillmann et al. 2017, Gottschling et al. 2018b), and we here perform the necessary combination. We are aware of ICN Rec. 56A.1. (Turland et al. 2018) that the name should not be used before decision of our proposal to conserve the type of Heterocapsa (Gottschling et al. 2018a). Although nomenclaturally correct at this moment in time, nobody will use the name H. triquetra as name for a species of Kryptoperidinium (Gottschling et al. 2018b). Therefore, we are confident in the usefulness to introduce the new name already today.

\section{Nomenclature and taxonomic activity}

Kryptoperidinium Er.Lindem., Botanisches Archiv. Zeitschrift für die gesamte Botanik 5: 116. 1924.

Type: Kryptoperidinium foliaceum (F.Stein) Er.Lindem.

Kryptoperidinium triquetrum (Ehrenb.) Tillmann, Gottschling, Elbr., Kusber \& Hoppenrath, comb. nov., basionym: Glenodinium triquetrum Ehrenb. in Bericht über die zur Bekanntmachung geeigneten Verhandlungen der Königlich Preussischen Akademie der Wissenschaften zu Berlin 1840: 200. 1840. Heterocapsa triquetra (Ehrenb.) F.Stein, syn. nov., Der Organismus der Flagellaten nach eigenen Forschungen in systematischer Reihenfolge bearbeitet 3.2: 13. 1883.-Type: Baltic Sea, off Germany. Mecklenburg-Vorpommern, Wismar, 5 Sep 1840: Ch.G. Ehrenberg s.n. [non-fossil].-Lectotype (designated in Gottschling et al. 2018b: [unpublished illustration] the lower of the two cells showing a flagellum present on drawing No. 674: BHUPM!).

= Glenodinium foliaceum F.Stein, syn. nov., Der Organismus der Flagellaten nach eigenen Forschungen in systematischer Reihenfolge bearbeitet 3.2: pl. III 22-26. 1883. Heterocapsa foliacea (F.Stein) Daday, nom. corr. (ICN Art. 23.5), Természetrajzi Füzetek 11: [76, ]99. 1888. Kryptoperidinium foliaceum (F.Stein) Er.Lindem., Botanisches Archiv. Zeitschrift für die gesamte Botanik 5: 116-117, figs 12-20. 1924. Peridinium foliaceum (F.Stein) Biecheler, Bulletin biologique de la France et de la Belgique / Supplément 36: 77[-81], figs 46-49. 1952.-Type: Baltic Sea, off Germany. Mecklenburg-Vorpommern, Wismar, probably late summer 1879 (Wetzel 1885): F. von Stein s.n. [nonfossil].-Lectotype (designated here: [illustration] Der Organismus der Flagellaten nach eigenen Forschungen in systematischer Reihenfolge bearbeitet 3.2: pl. III 24. 1883!).

Lectotypification also of $G$. foliaceum is advised, because we will never know whether all cells depicted in Stein (1883) were drawn from the same population and whether they were genetically identical. Figure 24 shows most completely various important traits such as the ventral flattening, multiple chloroplasts, the nucleus, the eyespot, the cingulum and the sulcus. The nomenclatural acts have been registered in PhycoBank under http://phycobank.org/100162 and http://phycobank. org/100163, respectively.

\section{References}

Anonymous (1954) Nomina generica conservanda. Taxon 3: 233. https://doi.org/10.2307/1216603

Chatton, É. (1952) Classe des dinoflagelles ou péridiniens. In: Grassé, P.-P. (Ed.) Phylogénie. Protozoaires : Généralités. Flagellés 1.1. Traité de Zoologie. Anatomie, systématique, biologie. Masson, Paris, pp. 309-406.

Dodge, J.D. (1971) A dinoflagellate with both a mesocaryotic and a eucaryotic nucleus. I. Fine structure of the nuclei. Protoplasma 73 : 145-157.

https://doi.org/10.1007/BF01275591

Ehrenberg, C.G.(1840) 274 Blätter von ihm selbst ausgeführter Zeichnungen von eben sovielen Arten. Berichte über diezur Bekanntmachung geeigneten Verhandlungen der Königlich Preussischen Akademie der Wissenschaften zu Berlin 1840: 197-219.

Figueroa, R.I., Bravo, I., Fraga, S., Garces, E. \& Llaveria, G. (2009) The life history and cell cycle of Kryptoperidinium foliaceum, a dinoflagellate with two eukaryotic nuclei. Protist 160: 285-300.

https://doi.org/10.1016/j.protis.2008.12.003 
Gottschling, M. \& McLean, T.I. (2013) New home for tiny symbionts: Dinophytes determined as Zooxanthella are Peridiniales and distantly related to Symbiodinium. Molecular Phylogenetics and Evolution 67: 217-222. https://doi.org/10.1016/j.ympev.2013.01.003

Gottschling, M., Tillmann, U., Kusber, W.-H., Hoppenrath, M. \& Elbrächter, M. (2018a) (2607) Proposal to conserve the name Heterocapsa (Dinophyceae) with a conserved type. Taxon 67: 632-633.

https://doi.org/10.12705/673.16

Gottschling, M., Tillmann, U., Kusber, W.-H., Hoppenrath, M. \& Elbrächter, M. (2018b) A Gordian knot: Nomenclature and taxonomy of Heterocapsa triquetra (Peridiniales: Heterocapsaceae). Taxon 67: 179-185. https://doi.org/10.12705/671.11

Horiguchi, T. \& Pienaar, R.N. (1994) Ultrastructure of a new marine sand-dwelling dinoflagellate, Gymnodinium quadrilobatum sp. nov. (Dinophyceae) with special reference to its endosymbiotic alga. European Journal of Phycology 29: 237-245. https://doi.org/10.1080/09670269400650691

Kempton, J., Wolny, J.L., Tengs, T., Rizzo, P., Morris, R., Tunnell, J., Scott, P., Steidinger, K., Hymel, S.N. \& Lewitus, A. (2002) Kryptoperidinium foliaceum blooms in South Carolina: A multi-analytical approach to identification. Harmful Algae 1: $383-392$. https://doi.org/10.1016/S1568-9883(02)00051-3

Kretschmann, J., Žerdoner Čalasan, A. \& Gottschling, M. (2018) Molecular phylogenetics of dinophytes harbouring diatoms as endosymbionts (Kryptoperidiniaceae, Peridiniales), with evolutionary interpretations and a focus on the identity of Durinskia oculata from Prague. Molecular Phylogenetics and Evolution 118: 392-402. https://doi.org/10.1016/j.ympev.2017.10.011

Lindemann, E. (1924) Der Bau der Hülle bei Heterocapsa und Kryptoperidinium foliaceum (Stein) n. nom. Botanisches Archiv 5: 114120.

Moestrup, Ø. \& Daugbjerg, N. (2007) On dinoflagellate phylogeny and classification. In: Brodie, J. \& Lewis, J. (Eds.) Unravelling the algae, the past, present, and future of algal systematics. CRC Press, Boca Raton, pp. 215-230. https://doi.org/10.1201/9780849379901.ch12

Moldrup, M., Moestrup, Ø. \& Hansen, P.J. (2013) Loss of phototaxis and degeneration of an eyespot in long-term algal cultures: Evidence from ultrastructure and behaviour in the dinoflagellate Kryptoperidinium foliaceum. Journal of Eukaryotic Microbiology 60: 327334. https://doi.org/10.1111/jeu.12036

Ross, R. [Special Committee for Bacillariophyta] (1952) Nomenclature Committees. Taxon 1: 95-97.

Saburova, M., Polikarpov, I. \& Al-Yamani, F. (2012) First record of Kryptoperidinium foliaceum (Dinophyceae: Peridiniales) from a hypersaline environment in Kuwait, north-western Arabian Gulf. Marine Biodiversity Records 5: e104. https://doi.org/10.1017/S1755267212000838

Schnepf, E. \& Elbrächter, M. (1999) Dinophyte chloroplasts and phylogeny — A review. Grana 38: 81-97. https://doi.org/10.1080/00173139908559217

Stein, F.v. (1883) Der Organismus der Infusionsthiere nach eigenen Forschungen in systematischer Reihenfolge bearbeitet 3.2. Engelmann, Leipzig.

Tillmann, U., Hoppenrath, M., Gottschling, M., Kusber, W.-H. \& Elbrächter, M. (2017) Plate pattern clarification of the marine dinophyte Heterocapsa triquetra sensu Stein (Dinophyceae) collected at the Kiel Fjord (Germany). Journal of Phycology 53: 1305-1324. https://doi.org/10.1111/jpy.12584

Turland, N.J., Wiersema, J.H., Barrie, F.R., Greuter, W., Hawksworth, D.L., Herendeen, P.S., Knapp, S., Kusber, W.-H., Li, D.-Z., Marhold, K., May, T.W., McNeill, J., Monro, A.M., Prado, J., Price, M.J. \& Smith, G.F. (2018) International Code of Nomenclature for algae, fungi, and plants (Shenzhen Code) adopted by the Nineteenth International Botanical Congress Shenzhen, China, July 2017. Regnum Vegetabile 159. Koeltz, Glashütten. Koeltz Scientific Books, Königstein, 254 pp. https://doi.org/10.12705/Code.2018

Wetzel, J. (1885) Hofrath Friedrich Ritter von Stein. Lotos - Zeitschrift für Naturwissenschaften 34: XXIII-XXXII.

Žerdoner Čalasan, A., Kretschmann, J. \& Gottschling, M. (2018) Absence of co-phylogeny indicates repeated diatom capture in dinophytes hosting a tertiary endosymbiont. Organisms Diversity \& Evolution 18: 29-38. https://doi.org/10.1007/s13127-017-0348-0 